\title{
Soft Tissue Sarcoma of the Retroperitoneum pNO TNM Finding v8
}

National Cancer Institute

\section{Source}

National Cancer Institute. Soft Tissue Sarcoma of the Retroperitoneum pNO TNM

Finding v8. NCI Thesaurus. Code C136809.

Soft tissue sarcoma of the retroperitoneum without regional lymph node metastasis or unknown lymph node status. (from AJCC 8th Ed.) 